\title{
Kıbrıs Endemik Bitkisi Origanum majorana: Sitma Tedavisinde Yeni Bir Alternatif Doğal Ürün Olabilir mi?
}

\section{An Endemic Plant of Cyprus, Origanum majorana: Is It A New Alternative Natural Product for Malaria Treatment?}

\author{
Emrah GÜLER ${ }^{1,6}($ ID $)$, Ahmet ÖZBiLGiN²(ID), Eda BECER ${ }^{3}(I D)$, Azmi HANOĞLU $^{4}(I D)$, \\ Tamer ŞANLIDAĞ ${ }^{5,6}($ ID) \\ ${ }^{1}$ Yakın Doğu Üniversitesi Tıp Fakültesi, Tıbbi Mikrobiyoloji ve Klinik Mikrobiyoloji Anabilim Dalı, Lefkoşa, KKTC. \\ ${ }^{1}$ Near East University Faculty of Medicine, Department of Medical Microbiology and Clinical Microbiology, Nicosia, TRNC. \\ ${ }^{2}$ Manisa Celal Bayar Üniversitesi Tıp Fakültesi, Tıbbi Parazitoloji Anabilim Dalı, Manisa. \\ ${ }^{2}$ Manisa Celal Bayar University Faculty of Medicine, Department of Medical Parasitology, Manisa, Turkey. \\ ${ }^{3}$ Yakın Doğu Üniversitesi Eczacılık Fakültesi, Biyokimya Anabilim Dalı, Lefkoşa, KKTC. \\ ${ }^{3}$ Near East University Faculty of Pharmacy, Department of Biochemistry, Nicosia, TRNC. \\ ${ }^{4}$ Yakın Doğu Üniversitesi Eczacılık Fakültesi, Farmasötik Botanik-Farmakognozi Anabilim Dalı, Lefkoşa, KKTC. \\ ${ }^{4}$ Near East University Faculty of Pharmacy, Department of Pharmaceutical Botany-Pharmacognosy, Nicosia, TRNC. \\ ${ }^{5}$ Manisa Celal Bayar Üniversitesi Tıp Fakültesi, Tıbbi Mikrobiyoloji Anabilim Dalı, Manisa. \\ ${ }^{5}$ Manisa Celal Bayar University Faculty of Medicine, Department of Medical Microbiology, Manisa, Turkey. \\ ${ }^{6}$ Yakın Doğu Üniversitesi, Deneysel Sağlık Bilimleri Araştırma Merkezi Enstitüsü, Lefkoşa, KKTC. \\ ${ }^{6}$ Near East University, Experimental Health Sciences Research Center Institute, Nicosia, TRNC.
}

* Bu çalışma, 21. Parazitoloji Kongresi (28 Eylül-03 Ekim 2019, izmir)'nde poster bildirisi olarak sunulmuştur.

Makale Atıfı: Güler E, Özbilgin A, Becer E, Hanoğlu A, Şanlıdağ T. Kıbrıs endemik bitkisi Origanum majorana: sıtma tedavisinde yeni bir alternatif doğal ürün olabilir mi? Mikrobiyol Bul 2020;54(3):463-478.

\section{ÖZ}

Sıtma, günümüzde halen önemini koruyan ve Dünya Sağlık Örgütünün de son yıllarda çok önem verdiği enfeksiyon hastalıklarından biridir. Sıtma ile savaş sonucunda Kıbrıs adasında 1948 yılından itibaren yerli sıtma olgusu rapor edilmemiştir. Son yıllarda tespit edilen olguların hepsi yurt dışı kaynaklı olgular şeklindedir. Bilindiği gibi yüzlerce ilaç bitkilerden elde edilmekte ve sıtmanın endemik olarak görüldüğü bölgelerde sıtma tedavisi için geleneksel ilaçlar kullanılmaktadır. Sıtma etkeni Plasmodium parazitlerinin antimalaryal ilaçlara karşı geliştirdikleri direnç sorunu nedeniyle, son yıllarda yeni ve güvenilir maddelerin elde edilmesi için bitki ekstrakt ve yağları üzerindeki araştırmalar hız kazanmıştır. Çalışmamızda, Kuzey Kıbrıs'ta yetişen Origanum dubium, Origanum majorana, Salvia fruticosa ve Laurus nobilis bitkilerinden elde edilen uçucu yağların, kemirgen sıtma etkeni Plasmodium berghei'ye karşı in vivo antimalaryal etkinliklerinin araştırılması amaçlanmıştır. Uygun mevsimlerde toplanıp kurutulan bitkilerin uçucu yağları Clevenger Apareyi sistemi ile elde edilmiş ve uçucu yağ analizleri yapılmıştır. Elde edilen uçucu yağların sitotoksik aktivitelerini saptamak amacıyla L929 fare fibroblast hücre hattı kullanılmış ve sitotoksisite MTT [3-(4.5-dimetiltiyazol-2-yl)-2.5-difeniltetrazolyum bromit] kiti ile tespit edilmiştir. Çalışmamızda, her grupta altışar fare (Balb/c) olacak şekilde, sıtma referans grubu olan klorokin grubu (KG) (50 mg/ 
$\mathrm{kg}$ ), tedavi almamış kontrol grubu (TAKG), O.dubium (OD) $(20 \mathrm{mg} / \mathrm{kg})$, O.majorana (OM) $(20 \mathrm{mg} / \mathrm{kg})$, S.fruticosa (SF) $(20 \mathrm{mg} / \mathrm{kg})$ ve L.nobilis (LN) $(20 \mathrm{mg} / \mathrm{kg})$ olmak üzere altı grup oluşturulmuş ve toplamda 36 fare ile çalışılmışıı. P.berghei suşu ile enfekte edilen farelere $0,1,2$ ve 3. günlerde (toplamda 4 kez) etken maddeler oral yolla verilmiştir. Son tedaviden 24 saat sonra her farenin kuyruk ucundan kan alınmış ve fareler ölene kadar her iki günde bir olacak şekilde kan alma işlemine devam edilmiştir. Toplanan kanlar ile ince yayma preparatları hazırlanarak Giemsa ile boyanmıştır. Ardından her yaymadaki parazitemi yüzdeleri hesaplanmıştır. Yapılan sitotoksisite testleri sonucunda OD uçucu yağı hariç diğer yağlarda $100 \mu \mathrm{g} /$ $\mathrm{ml}(20 \mathrm{mg} / \mathrm{kg})^{\prime}$ de sitotoksik aktiviteye rastlanmamıştır. Klorokin alan fareler 6. gün paraziteminin ortadan kalkmasıyla yaşamlarına devam ederken, TAKG'de yer alan fareler 9. günde ölmüştür. Parazitemi oranı, OM grubundaki farelerde 23. gün, OD grubundaki farelerde 21. gün, diğer gruplardakilerde ise 14. günde \%35 seviyesine ulaşmış ve fareler ölmüştür. Çalışmamızda, tüm gruplardaki yaşam süresi ortalamaları arasındaki fark istatistiksel olarak anlamlı bulunmuştur $(p \leq 0.001)$. Sonuç olarak, antimalaryal etki gösteren, parazitemiyi düşürerek farelerin yaşam süresini iki katından fazla artıran, Kıbrıs endemik bitkilerinden O.majorana (TAKG'ye göre 14 gün artış) ve yine aynı cinsten O.dubium (TAKG'ye göre 12 gün artış)'un, antimalaryal moleküllerin elde edilmesine kaynaklık edebileceği düşünülmektedir.

Anahtar kelimeler: Plasmodium berghei; uçucu yağ; in vivo; antimalaryal etkinlik; Kuzey Kıbrıs Türk Cumhuriyeti.

\section{ABSTRACT}

Malaria still remains to be a public health threat and one of the most important infectious diseases to get attention from World Health Organization. No domestic malaria cases have been reported on the island of Cyprus since 1948, as a result of successful elimination process. All of the malaria cases detected in recent years are imported cases. As known, hundreds of medicines are obtained from plants and traditional medicine are used in endemic places of malaria. The cause of malaria - Plasmodium parasites, are developing resistance to antimalarial drugs. Hence, research on plant extracts and essential oils have gained great interest in recent years to obtain new and safe agents/substances. In our study, it was aimed to investigate the in vivo antimalarial activities of essential oils obtained from Origanum dubium, Origanum majorana, Salvia fruticosa and Laurus nobilis plants which grows in Northern Cyprus against Plasmodium berghei - the rodent malaria agent. Plants were collected in appropriate seasons and were dried to obtain and analyze essential oils via Clevenger Apparatus system. L929 mouse fibroblast cell line and MTT [3-(4.5-dimethylthiazole-2-yl) -2.5-diphenyltetrazolium bromide] kit were used to determine the cytotoxic activities of the essential oils obtained. In our study, total of 36 mice (Balb/c) of 6 groups (6 mice in each group) were formed: chloroquine group (CG) $(50 \mathrm{mg} / \mathrm{kg})$ as malaria reference group, untreated control group (UTCG), O.dubium (OD) $(20 \mathrm{mg} / \mathrm{kg})$, O.majorana (OM) $(20 \mathrm{mg} / \mathrm{kg})$, S.fruticosa (SF) $(20 \mathrm{mg} / \mathrm{kg})$ and L.nobilis (LN) $(20 \mathrm{mg} / \mathrm{kg})$. The essential oils were given to mice infected with P.berghei strain orally on $0,1,2$ and $3^{\text {rd }}$ days ( 4 times in total). Blood was taken from the tail end of each mouse 24 hours after the last treatment and blood collection was continued every two days until the mice died. Withdrawn blood taken from the mice were prepared as a thin smear and stained with Giemsa. Then, parasitemia percentages in each smear were calculated. As a result of the cytotoxicity tests, cytotoxic activity was not found at $100 \mu \mathrm{g} / \mathrm{ml}(20 \mathrm{mg} / \mathrm{kg})$ in all oils except OD essential oil. While the mice receiving chloroquine continued their lives with the disappearance of the parasite on the $6^{\text {th }}$ day, the mice in the UTCG died on the $9^{\text {th }}$ day. The parasitemia rate reached $35 \%$ in the OM group on the $23^{\text {rd }}$ day, in the OD group on the $21^{\text {st }}$ day and in the other groups (SF and LN) on the $14^{\text {th }}$ day and the mice have died. In our study, the difference between the life span in all groups was found statistically significant $(p \leq 0.001)$. As a result, the essential oils O.majorana (14 days increase according to UTCG) an endemic plant of Cyprus and O.dubium (12 days increase according to UTCG) which had an antimalarial effect, decreased parasitemia and increased the life span of mice more than two times, indicated that they could be a source for the acquisition of new antimalarial molecules.

Keywords: Plasmodium berghei; essential oil; in vivo; antimalarial activity; Turkish Republic of Northern Cyprus. 


\section{Giriş}

Plasmodium türü parazitlerin neden olduğu sıtma, dünyanın birçok ülkesinde endemik olması ve eradike edildiği bölgelerde importe olgular şeklinde ortaya çıkması nedeniyle küresel bir halk sağlığı sorunu olmaya devam etmektedir ${ }^{1}$. En eski insan enfeksiyonlarından biri olan sıtma, son yıllarda Dünya Sağlık Örgütü (DSÖ)'nün üzerinde durduğu asıl problemlerden sayılmaktadır². Özellikle 2000 yılından itibaren sıtmaya karşı açılan savaş sonucu hastalığın insidansında \%41'lik bir azalma görülmüştür. Sıtma mücadelesi ile 2000-2015 yılları arasındaki 15 yıllık dönemde hastalığın endemik olduğu ülkelerin sayısı 108'den 91'e düşmüştür. Buna rağmen, diğer bir açıklamaya göre 2015-2017 yılları arasında sıtma insidansında anlamlı bir azalmanın olmadığı iddia edilmektedir ${ }^{3,4}$. DSÖ verilerine göre 2018 yılında dünyada 228 milyon sıtma olgusu bildirilmiş ve 405.000 kişinin sıtma enfeksiyonundan hayatını kaybettiği belirlenmiştir. Tüm olguların yaklaşık \%93'ü, sıtma kaynaklı ölümlerin ise \%94'ü Afrika kıtasında saptanmış, ölümlerin \%67 (272.000)'sini beş yaş altı çocukların oluşturduğu görülmüştür ${ }^{5}$.

Kıbrıs, Akdeniz'in birçok bölgesinde olduğu gibi, yüzyıllarca sıtmadan en çok etkilenen bölgelerdendir. 1878 yılında adada İngiliz yönetimi hüküm sürmeye başlamış ve sıtma felaketine karşı çeşitli önlemler almıştır. Hem adaya gelen İngiliz üst düzey yöneticilere ve Ingiliz askerlere hem de yerli halka, sıtmadan korunmak amacıyla kinin ilacı dağıtılmıştır. Ayrıca tüm adada, su emici özelliği ile bilinen okaliptüs cinsi ağaçlar ekilerek bataklık alanlar kurutulmuştur. Sonuç olarak, 1948 yılında Kıbrıs'ta Plasmodium parazitlerinin taşıyıcısı olan söz konusu Anopheles sivrisineğinin tümüyle yok edilmesi başarıyla sağlanmıştır6 Günümüzde, Kuzey Kıbrıs'ta yerli sıtma olgusu görülmemekte olup, olguların tümü yurt dışı kaynaklıdır. Kuzey Kıbrıs Türk Cumhuriyeti (KKTC) Sağlık Bakanlığı verilerine göre adada 2014-2018 yılları arasında toplam 39 yurt dışı kaynaklı sıtma olgusu görülmüştür. Sıtma, ülkemizde bildirimi zorunlu hastalıklar arasında yer almaktadır ${ }^{7}$.

Dünya nüfusunun $\% 75^{\prime}$ ten fazlası çeşitli enfeksiyonların tedavisinde tıbbi bitkileri kullanmakta ve bilindiği gibi yüzlerce ilaç, bu bitkilerden elde edilmektedir. Sıtma tedavisinde de geleneksel ilaçların kullanımı özellikle sıtmanın endemik olduğu bölgelerde yaygındır. Bitkilerden elde edilen maddelerin, ileride yapılacak olan antimalaryal ilaç çaIışmalarında potansiyeli yüksek bir kaynak oluşturabileceği düşünülmektedir. Yıllarca, bitkilerin veya bitkilerden elde edilen ekstraktların/yağların çeşitli enfeksiyonların tedavisinde etkili bir kaynak oluşturduğu bilinmektedir. Sıtma enfeksiyonu ise halen tüm dünyada ciddi bir sağlık sorunu olarak karşımıza çıkmakta ve antimalaryal ilaçlara karşı Plasmodium parazitlerinin geliştirdiği direnç sorunundan dolayı yeni ve etkili ilaçların keşif çalışmaları sürmektedir $^{8,9}$. Günümüzde var olan hemen hemen tüm antimalaryal ilaca karşı belirli bir düzeyde direncin geliştiği görülmüş ve önüne geçilmediği takdirde ilaca dirençli sıtma sorununun ileriki yıllarda giderek artan bir halk sağlığı problemi haline geleceği öngörülmüştür ${ }^{10}$.

Çalışmamızda, Kuzey Kıbrıs'ta yetişen Origanum dubium (OD), Origanum majorana (OM), Salvia fruticosa (SF) ve Laurus nobilis (LN) bitkilerinden elde edilen uçucu yağların, 
en tehlikeli insan sıtma etkeni olan Plasmodium falciparum'a benzer bir klinik tablo oluşturan kemirgen sıtma etkeni Plasmodium berghei'ye karşı in vivo antimalaryal etkinliklerinin araştırılması amaçlanmıştır. Fareler üzerinde yapılan bu çalışmada, sıtmaya karşı alternatif, yeni ve güvenilir ilaç potansiyellerinin saptanması hedeflerimiz arasındadır. Araştırmamız, bu konuyla ilgili ülkemizde yapılan ilk çalışma olma özelliğindedir.

\section{GEREÇ ve YÖNTEM}

Bu çalışma, Yakın Doğu Üniversitesi Hayvan Deneyleri Yerel Etik Kurulu onayı ile gerçekleştirildi (Tarih: 27.03.2019 ve Karar no: 2019-03).

\section{Bitkilerin Toplanması ve Kurutulması}

Bu çalışmada kullanılan tüm bitkiler, Yakın Doğu Üniversitesi Eczacılık Fakültesi, Farmasötik Botanik-Farmakognozi Anabilim Dalı tarafından Kuzey Kıbrıs'ın çeşitli bölgelerinden toplandı (Tablo I). Tür tanımlaması yapıldı ve Yakın Doğu Üniversitesi (YDÜ) Herbaryum Merkezinde (OM no: NEUN 6895, OD no: NEUN 6896, SF no: NEUN 6897, LN no: NEUN 6898) saklandı. Karanlık ortamda kurutulan bitkiler, yağ verimini artırmak amacıyla steril makas ile küçük parçalara bölündü. Kuru materyaller Clevenger Apareyi sistemi kullanılarak distilasyona tabii tutuldu ve üç saatlik distilasyon sonrasında bitkilere ait uçucu yağlar elde edildi. Daha sonra kuru baz üzerinden verim hesabı yapılıp piknometre yardımıyla yağların öz kütleleri hesaplandı. Tüm uçucu yağlar $+4^{\circ} \mathrm{C}^{\prime} \mathrm{de}$, kullanılacağı zamana kadar muhafaza edildi.

\section{Uçucu Yağların Analizleri}

Gaz kromatografisi ve kütle spektrometresi analizleri (GC-MS) Agilent 5975 GC-MSD sistemi kullanılarak gerçekleştirildi. Innowax FSC kolonunda (60 m x 0.25 m film kalınlığı) taşıyıcı gaz olarak helyum gazı $(0.8 \mathrm{ml} / \mathrm{dk})$ kullanıldı. GC fırın sıcaklığı, 10 dakika boyunca $60^{\circ} \mathrm{C}^{\prime}$ de tutuldu ve her dakikada $1^{\circ} \mathrm{C}$ artacak şekilde $220^{\circ} \mathrm{C}^{\prime}$ ye programlandı. Bölünme oranı $40 / 1$ ve enjektör sıcaklığı $250^{\circ} \mathrm{C}$ olarak ayarlandı. Kütle aralığı m/z 35 ile 450 idi ve kütle spektrumları $70 \mathrm{eV}^{\prime}$ de kaydedildi.

GC analizi, Agilent 6890N GC sistemi kullanılarak yapıldı. Alev iyonizasyon dedektörünün (FID) sıcaklığı $300^{\circ} \mathrm{C}$ olarak ayarlandı. GC-MS ile aynı elüsyon sırasını elde etmek için, aynı kolonun bir kopyasına aynı koşullarda eş zamanlı olarak otomatik enjeksiyon yapıldı. Ayrılan bileşiklerin yüzdesi FID kromatogramlarından hesaplandı.

\begin{tabular}{|lccc}
\hline \multicolumn{4}{|l|}{ Tablo I. Çalışmamızda Kullanılan Bitkisel Materyallere Ait Bilgiler } \\
\hline Bitki adı & Bitkinin Türkçe adı & Toplanan kısım & Lokasyon \\
\hline Origanum majorana* & Mercanköşk & Toprak üstü kısımları & St. Hilarion Kalesi/Girne \\
Origanum dubium & Kekik & Toprak üstü kısımları & Yeşilırmak/Lefke \\
Salvia fruticosa & Adaçayı & Toprak üstü kısımları & Zeytinlik/Girne \\
Laurus nobilis & Defne & Yaprak & Bostancı/Güzelyurt \\
\hline * Endemik tür. & & & \\
\hline
\end{tabular}




\section{Sitotoksisite Analizleri}

Elde edilen uçucu yağların sitotoksik aktivitelerini saptamak için L929 fare fibroblast hücre hattı (American Type Culture Collection, ABD) kullanıldı. L929 hücreleri DMEM (Dulbecco's Modified Eagle Medium) (Biological Industries, 01-050-1A) besiyerinde \%10 ısı ile inaktive edilmiş fetal sığır serumu (Fetal Bovine Serum, FBS) (Capricorn Scientific, FBS-11B), \%1 penisilin-streptomisin (Biochrom, A2213) ve \%1 glutamin (EMD Millipore, K0282) eklenerek $37^{\circ} \mathrm{C}^{\prime} \mathrm{de}, \% 5 \mathrm{CO}_{2}^{\prime}$ li ortamda çoğaltıldı. Besiyerinde çoğaltılan hücreler ile uçucu yağlar muamele edildi ve MTT [3-(4.5-dimetiltiyazol-2-yl)-2.5difeniltetrazolyum bromit] kiti (Glentham Code, GT3156) kullanılarak sitotoksik aktiviteleri belirlendi.

MTT, canlı hücreler tarafından indirgenen mor formazan bir ürün olan 3-(4.5-dimetiltiyazol-2-yl)-2.5 difeniltetrazolyum bromitin redüksiyonunun kolorimetrik ölçümüne dayanır. OD, OM, SF ve LN uçucu yağları, dimetilsülfoksit (DMSO, SigmaAldrich) kullanılarak $100 \mathrm{mg} / \mathrm{ml}$ olacak şekilde hazırlandı ve beş farklı $(5 \mu \mathrm{g} / \mathrm{ml}, 10 \mu \mathrm{g} /$ $\mathrm{ml}, 25 \mu \mathrm{g} / \mathrm{ml}, 50 \mu \mathrm{g} / \mathrm{ml}$ ve $100 \mu \mathrm{g} / \mathrm{ml}$ ) konsantrasyondaki kültür ortamında seyreltildi. L929 fare fibroblast hücreleri, 96 kuyucuklu kültür kaplarına her bir kuyucukta $100 \mu \mathrm{l}$ (5 x $10^{3} / \mathrm{ml}$ hücre yoğunluğu) gelecek şekilde ekildi. Kör, hücre ve ekstrakt içermemekte iken negatif kontrolde sadece ekilmiş hücreler bulunmaktaydı. OD, OM, SF ve LN dilüsyonları hücre hattı içerisinde 24-48 saat inkübasyonda bırakıldı. Ardından MTT çözeltisi $37^{\circ} \mathrm{C}^{\prime}$ ye ısıtıldı ve daha sonra her bir kuyucuğa $10 \mu$ gelecek şeklinde eklendi. Dört saat $37^{\circ} \mathrm{C}^{\prime} \mathrm{de}$, \%5 $\mathrm{CO}_{2}{ }_{2}^{\prime l i}$ ortamda inkübe edildikten sonra, formazan tuzlarını çözmek için $50 \mu$ l DMSO eklendi. Absorbans, spektrofotometre (Versa Max, Molecular Device, Sunnyvale, ABD) ile 540 nm'de ölçüldü. Tüm deneyler her ekstrakt için üç kez tekrarlanarak gerçekleştirildi.

\section{Deney Hayvanları ve Çalışma Grupları}

Her biri 8-12 haftalık, yaklaşık 20-25 gram ağırlığında olan dişi Balb/c türü fareler kullanıldı. Tüm gruplardaki fareler standart hayvan yemi ile beslenip, içme suyu olarak temiz çeşme suyu verildi ${ }^{11}$. Fareler, YDÜ Deney Hayvanları Araştırma Merkezinde bulunmaktaydı ve tüm deney süresince hayvan haklarına sadık kalınarak çalışmalar yapıldı.

Çalışmamızda, her grupta altışar fare olacak şekilde, sıtma referans grubu olan klorokin (Sigma, Saint Louis, MO 63103, ABD) grubu (KG) $(50 \mathrm{mg} / \mathrm{kg})^{11}$, tedavi almamış kontrol grubu (TAKG), O.dubium (OD) $(100 \mu \mathrm{g} / \mathrm{ml}=20 \mathrm{mg} / \mathrm{kg})$, O. majorana (OM) (100 $\mu \mathrm{g} / \mathrm{ml}=20 \mathrm{mg} / \mathrm{kg})$, S.fruticosa (SF) $(100 \mu \mathrm{g} / \mathrm{ml}=20 \mathrm{mg} / \mathrm{kg})$ ve L.nobilis (LN) $(100 \mu \mathrm{g} / \mathrm{ml}=$ $20 \mathrm{mg} / \mathrm{kg}$ ) olmak üzere 6 grup oluşturuldu ve toplamda 36 fare ile çalışıldı.

\section{P.berghei Suşu}

Çalışmamızın hayvan deneyleri kısmında, fareleri enfekte etmek amacıyla MR4-ATCC (American Type Culture Collection, Virjinya, ABD) firmasından elde edilen MRA-311 P.berghei suşu kullanıldı. P.berghei suşu, Manisa Celal Bayar Üniversitesi Tıp Fakültesi, Tıbbi Parazitoloji Laboratuvarında farelere 10 günde bir intravenöz pasajlar yapılarak 
canlılığı devam ettirildi ve dereceli dondurma yöntemiyle kriyoprezervasyonu yapılarak SıVı azot tankında saklandı. Daha sonra üniversitemiz hastanesi Mikrobiyoloji Laboratuvarında $-80^{\circ} \mathrm{C}^{\prime}$ de muhafaza edildi. P.berghei ile enfekte eritrosit süspansiyonu $37^{\circ} \mathrm{C}^{\prime}$ lik su banyosunda 10 dakika çözüldükten sonra, 2 tane fareye intraperitoneal bölgeden verildi. Her iki günde bir, bu farelerin kuyruk ucundan kan alınarak, Giemsa ile boyalı preperatlar hazırlandı ve her aşamada parazitemi izlenip, kayıt altına alındı. Farelerdeki parazitemi oranı \%30-35'e ulaştığı zaman ise farelere ötenazi uygulanarak, kalplerinden kan alındı.

\section{Farelere İnokülasyon ve Tedavi (4 gün testi)}

Parazitemisi istenilen seviyeye ulaşan iki fareden birinin kalbinden yaklaşık $0.1 \mathrm{ml}$ kan alınıp, $9.9 \mathrm{ml}$ RPMI 1640 besiyeri (Biological Industries, İsrail) (toplam hacim $10 \mathrm{ml}$ ) içerisinde homojen bir şekilde karışım sağlandı. Çalışma gruplarında bulunan her fareye, hazırlanan P.berghei'li eritrosit süspansiyonundan $0.2 \mathrm{ml}\left(2 \times 10^{7}\right)$ periton bölgesinden enjekte edildi. Enfeksiyondan 3 saat sonra ilk tedavi dozları (0. gün) tüm farelere intragastrik gavaj yöntemiyle oral yolla verildi. Daha sonra aynı miktarda tedavi 24. (1. gün), 48. (2. gün) ve 72. (3. gün) saatlerde (toplam 4 doz) tekrarlandı. Son tedaviden 24 saat sonra tüm farelerin kuyruk ucundan kan alınıp, ince damla kan yaymaları hazırlandı. Kan alımına, fareler eksitus olana kadar her iki günde bir olacak şekilde devam edildi ${ }^{11}$.

\section{Yaymaların Boyanması}

Yaymalar kuru sıcak havada kurutulduktan sonra, 3 dakika metanolde bekletildi. Daha sonra metanolün fazlası dökülüp, su ile yıkama yapmadan direkt olarak kurumaya bırakıldı. Tamamen kuruyan yaymalar, $10 \mathrm{ml}$ distile suya 10 damla Giemsa ana boyası $(1 \mathrm{ml}$ distile su için 1 damla Giemsa oranına göre) eklenerek hazırlanmış Giemsa solüsyonu ile 45 dakika muamele edildikten sonra su ile yıkanıp kurutuldu ${ }^{12}$ ve $100 x$ objektifte immersiyon yağı kullanılarak incelendi. İncelenen kan yaymalarındaki parazitemi yüzdeleri hesaplandı ve kayıt altına alındı.

\section{Paraziteminin Hesaplanması}

Farelerdeki parazitemi hesaplanmasında; 10 alanda 100'er eritrosit sayılıp enfekte eritrositlerin yüzdeleri hesaplanarak toplandı. Elde edilen değer 10 sahanın ortalamasını almak için 10'a bölünüp, farelerdeki ortalama parazitemi yüzdesi belirlendi ${ }^{11}$.

\% Parazitemi: (Enfekte eritrosit sayısı/Toplam eritrosit sayısı) x 100

\section{İstatistiksel Analiz}

Verilerin tüm istatistiksel analizlerinde SPSS (Statistical Package of the Social Sciences) Demo Ver 22 (SPSS Inc., Chicago, IL, ABD) programı kullanıldı. Illk olarak her bir gruptaki verilerin normal dağılıma uyup uymadıklarını belirlemek amacıyla Kolmogorov-Smirnov testi uygulandı. Kolmogorov-Smirnov testine göre eğer veriler normal dağılıma uyuyorsa $p>0.05$, uymuyorsa $p<0.05$ olmalıdır. Tüm gruplarda bulunan farelerin yaşam süreleri arasındaki anlamlıı̆̆ı belirlemek amacıyla ise Tek Yönlü Varyans Analizi (One-way ANO- 
VA) testi yapıldı. Gruplar arasındaki ikişerli farkları görmek için ise Dunnett ve Tukey HSD testlerine başvuruldu. Tüm testlerde $p<0.05$ düzeyindeki sonuçlar anlamlı kabul edildi.

\section{BULGULAR}

Çalışmamızda kullanılan uçucu yağların majör bileşikleri Tablo II'de gösterilmiştir.

L929 fare fibroblast hattı, hücre kültüründe farklı konsantrasyonlardaki OD, OM, SF ve $L N$ uçucu yağları ile 24 ve 48 saatlik sürelerde inkübe edilmiştir. Bu konsantrasyonlar sırasıyla 5, 10, 25, 50 ve $100 \mu \mathrm{g} / \mathrm{ml}^{\prime}$ dir. MTT sonuçlarına göre genel olarak, L929 fare fibroblast hücrelerinde yağ konsantrasyonlarının dozu yükseldikçe doza bağlı olarak hücre canlılığının azaldığı görülmüştür. OD yağı ile 24 ve 48 saat inkübe edilmiş $L 929$ fare fibroblast hücrelerinde hücre canlılığının özellikle yüksek dozlarda $(25-100 \mu \mathrm{g} / \mathrm{ml})$ çok az olduğu belirlenmiştir. Bunlara ek olarak, OM uçucu yağı ile inkübe edilen hücrelerin, özellikle $100 \mu \mathrm{g} / \mathrm{ml}$ dozunda ve 48 saat inkübasyon sonunda yaklaşık yarısının (\%50) canlıığını kaybettiği görülmüş, düşük dozlarda ise hücre canlıı̆̆ı stabil kalmıştır. LN uçucu yağının ise tüm dozlardaki 24 saatlik inkübasyonlarında hücre canlılıklarında anlamlı bir azalma izlenmezken, 48 saat inkübasyon sonunda hücre canlılığı yaklaşık \%50 azalmıştır. Hücre kültüründe, SF uçucu yağının hücre canlılığına olumsuz etki göstermediği tespit edilmiştir. Bitki yağlarının $100 \mu \mathrm{g} / \mathrm{ml}^{\prime}$ deki sitotoksik aktivite sonuçları Şekil 1-4'te görülmektedir.

Farelerin 4. gün yapılan değerlendirmelerinde, OD grubunda \%2, OM grubunda \%3, klorokin grubunda \%0.25, TAKG'de \%6 ve diğer bitki yağlarının (SF ve LN) verildiği gruplarda ise $\% 5$ ortalama parazitemi yüzdeleri saptanmıştır. Klorokin alan fareler 6. gün paraziteminin ortadan kalkmasıyla yaşamlarına devam ederken, TAKG'de yer alan fareler 9. günde eksitus olmuştur. Parazitemi oranı, OM grubundaki farelerde 23. gün, OD grubundaki farelerde 21. gün, diğer gruplardakilerde ise 14. günde $\% 35^{\prime}$ e ulaşmış ve fareler eksitus olmuşlardır (Şekil 5). TAKG'ye göre, OM ve OD grubunda bulunan farelerin yaşam sürelerinde sırasıyla 14 ve 12 gün, SF ve LN'nin her ikisinde ise beşer gün artış olduğu görülmüştür (Tablo III). Tüm gruplarda yer alan farelerin 8. günde hazırlanmış Giemsa boyaIı preparatlarından çekilmiş görüntüleri Resim 1-6'da gösterilmiştir. Çalışmamız süresince kullanılan farelerin hiçbirinde sıtma dışı herhangi bir nedenden dolayı ölüm görülmemiş, tüm farelerde başarılı bir şekilde enfeksiyon oluşturulmuştur.

\begin{tabular}{|lccccccc|}
\hline \multicolumn{7}{|l|}{ Tablo II. Uçucu Yağların lç̧eriğinde Bulunan Majör Bileşikler } \\
\hline OD & $\%$ & OM & $\%$ & SF & $\%$ & LN & $\%$ \\
\hline Karvakrol & 81.8 & cis-Sabinen hidrat & 29.1 & 1.8 -Sineol & 43.9 & 1.8 -Sineol & 57.2 \\
$p$-Simen & 5.0 & Terpinen-4-ol & 19.6 & Kamfor (Kafur) & 14.0 & $\alpha$-Terpinil asetat & 9.4 \\
Myrcene & 1.9 & $\gamma$-Terpinen & 9.5 & Kamfen & 8.8 & Sabinen & 6.7 \\
Terpinen-4-ol & 0.8 & $\alpha$-Terpineol & 5.8 & $\alpha$-Pinen & 6.6 & Terpinen-4-ol & 4.3 \\
$\alpha$-Terpineol & 0.8 & $\alpha$-Terpinen & 5.7 & $\beta$-Pinen & 5.8 & $\alpha$-Pinen & 4.1 \\
\hline OD: Origanum dubium, OM: Origanum majorana, SF: Salvia fruticosa, LN: Laurus nobilis. \\
\hline
\end{tabular}




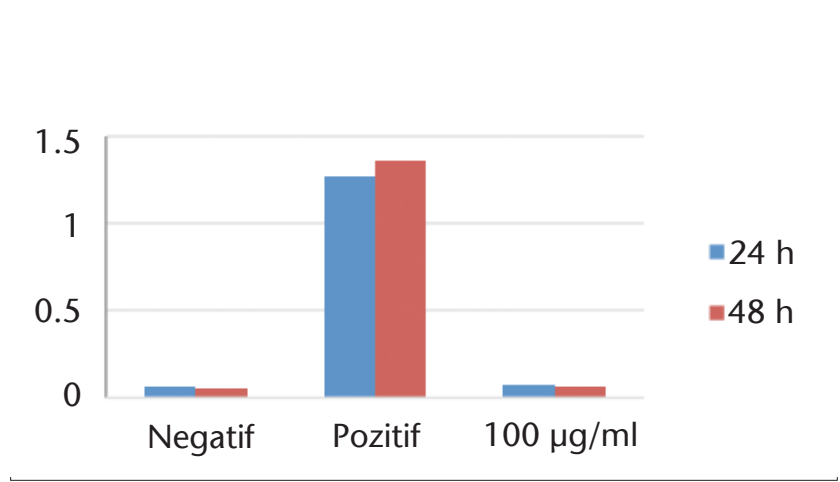

Şekil 1. Origanum dubium sitotoksik aktivitesi.

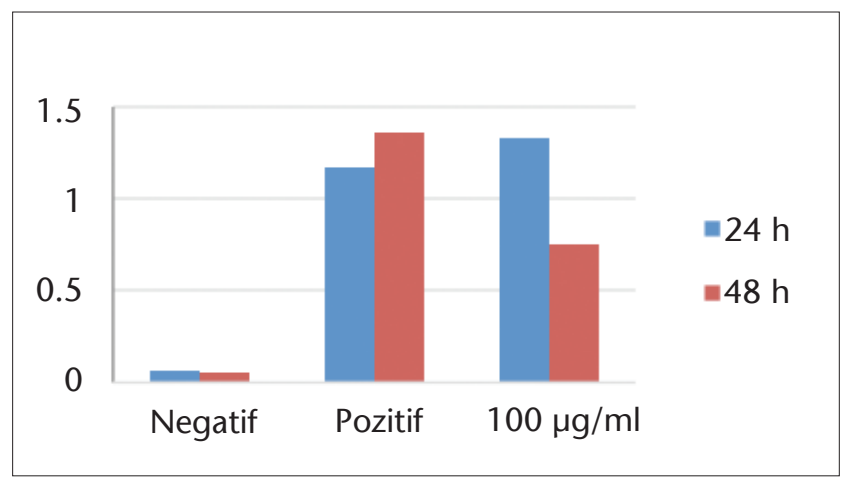

Şekil 2. Laurus nobilis sitotoksik aktivitesi.

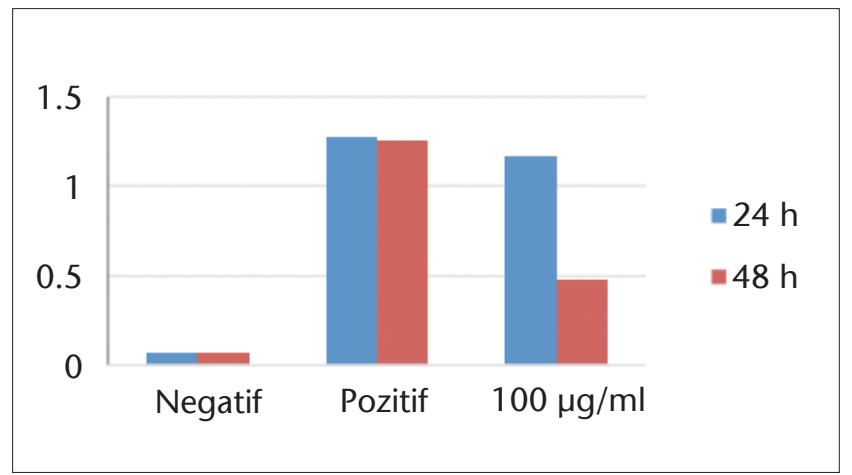

Şekil 3. Origanum majorana sitotoksik aktivitesi.

\section{İstatistiksel Analiz Sonuçları}

Çalışmamızda, her bir gruptaki farelere ait yaşam sürelerine dair verilerin normal dağılıma uyduğu görülmüş̧ür. Buna göre, Kolmogorov-Smirnov testi sonucundaki $p$ değerleri OM, OD, SF, LN ve TAKG'de sırasıyla $p=0.792, p=0.991, p=0.748, p=0.612$ ve 


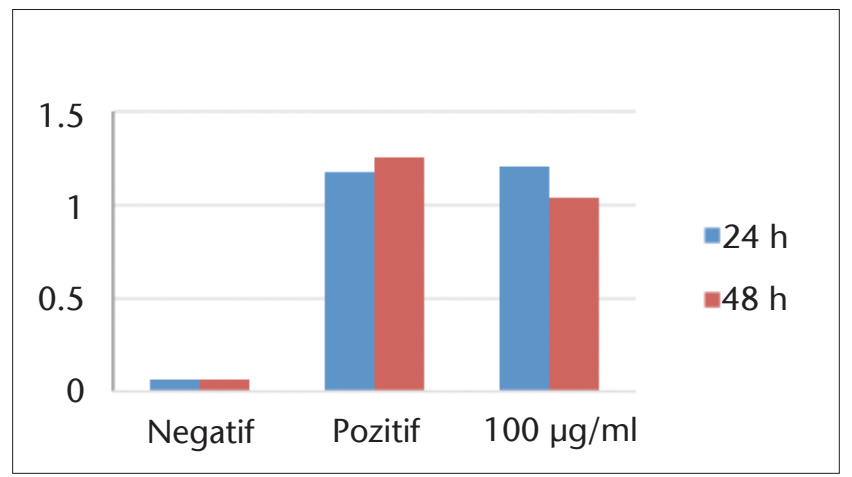

Şekil 4. Salvia fruticosa sitotoksik aktivitesi.

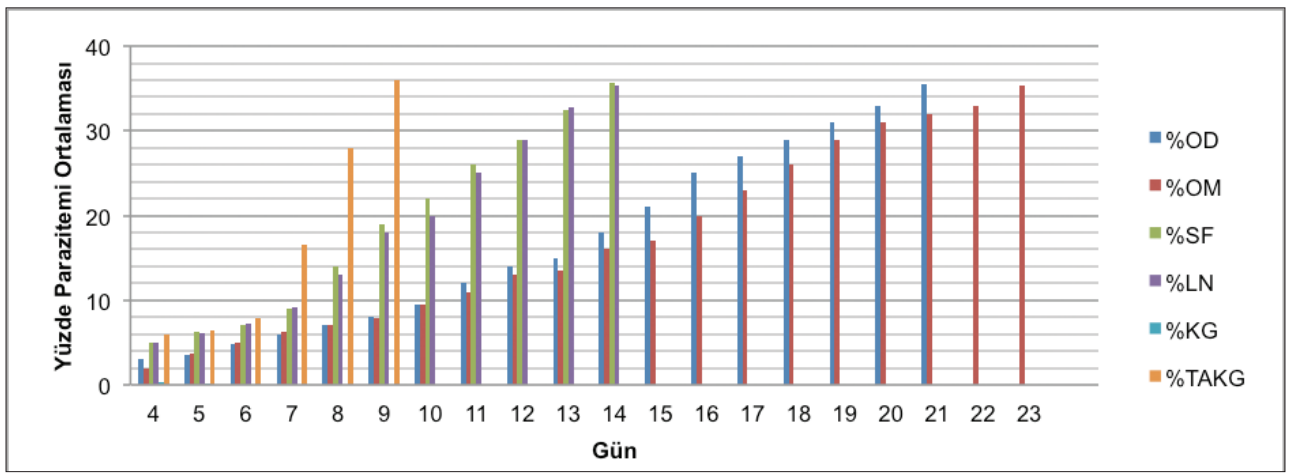

Şekil 5. Günlere göre yüzde parazitemi ortalamalarının dağılımı.

$\mathrm{p}=0.988^{\prime}$ dir. Tüm gruplardaki yaşam süreleri ortalamaları arasındaki fark istatistiksel olarak anlamlı (önemli) bulunmuştur ( $\mathrm{p} \leq$ 0.001) (Tablo IV).

Yaşam sürelerine ilişkin farkın önemli bulunması ve gruplardan birisinin kontrol grubu (TAKG) olmasından dolayı, grupların kontrol grubuna göre karşılaştırmalarında 'Post Hoc' testlerinden 'Dunnett' testi kullanılmıştır. Buna göre;

- $\quad$ OM ile TAKG arasındaki fark istatistiksel olarak önemlidir $(p<0.0001)$.

- $\quad$ OD ile TAKG arasındaki fark istatistiksel olarak önemlidir $(p<0.0001)$.

- $\quad$ SF ile TAKG arasındaki fark istatistiksel olarak önemlidir $(p<0.001)$.

- $\quad$ LN ile TAKG arasındaki fark istatistiksel olarak önemlidir $(p<0.001)$.

Çalışma gruplarındaki ortalama yaşam sürelerinin (kontrol grubu dışında) birbirleri arasındaki farkının anlamlıık düzeyini tespit etmek amacıyla Tukey HSD testi kullanılmıştır. OM-OD ile SF-LN hariç, diğer gruplar arasındaki farkın istatistiksel olarak anlamlı olduğu görülmüştür. Test sonuçları Tablo V'te verilmektedir. 


\begin{tabular}{|lcccccc|}
\hline \multicolumn{7}{|l|}{ Tablo III. Çalışma Gruplarında Günlere Göre Ortalama Parazitemi Oranları (\%) } \\
\hline Gün & OM (\%) & OD (\%) & SF (\%) & LN (\%) & TAKG (\%) & KG (\%) \\
\hline 4. & 2 & 3 & 5 & 5 & 6 & 0.25 \\
6. & 5 & 4.8 & 7 & 7.2 & 7.8 & 0 \\
8. & 7 & 7.1 & 14 & 13 & 28 & 0 \\
9. & 7.9 & 8 & 19 & 18 & $36^{*}$ & 0 \\
10. & 9.4 & 9.5 & 22 & 20 & - & 0 \\
12. & 13 & 14 & 29 & 28.9 & - & 0 \\
13. & 13.5 & 15 & 32.5 & 32.8 & - & 0 \\
14. & 16 & 18 & $35.6^{*}$ & $35.4^{*}$ & - & 0 \\
16. & 20 & 25 & - & - & - & 0 \\
18. & 26 & 29 & - & - & - & 0 \\
20. & 31 & 33 & - & - & - & 0 \\
21. & 32 & $35.5^{*}$ & - & - & - & 0 \\
22. & 34.5 & - & - & - & - & 0 \\
23. & $35.3^{*}$ & - & - & - & - & 0 \\
\hline * Eksitus. & & & & & & \\
\hline
\end{tabular}

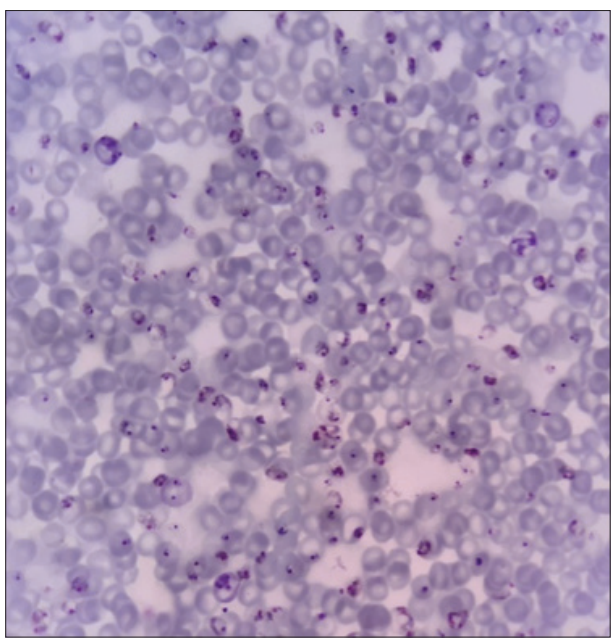

Resim 1. TAKG 8. gün (\%28 parazitemi).

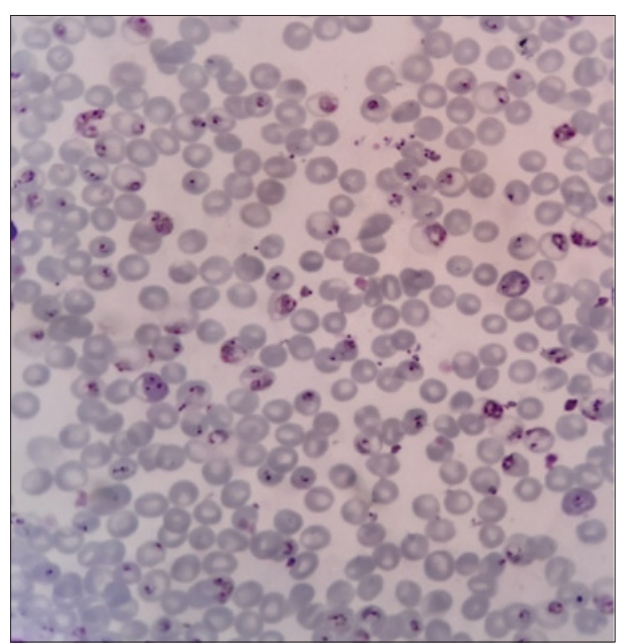

Resim 2. LN (20 mg/kg) 8. gün (\%13 parazitemi).

\section{TARTIŞMA}

Çalışmamızda, ülkemizde yetişen bazı bitkilerin antimalaryal aktiviteye sahip olup olmadıkları araştırımıştır. Bitkisel ürünlerin, genellikle sentetik olanlara göre daha az toksik ve daha az yan etkiye sahip olduğu düşünülmektedir. Giderek artan sayıda insan, bitkilerden elde edilen ilaçlar ile alternatif tedaviyi kullanmaktadır. Örneğin 


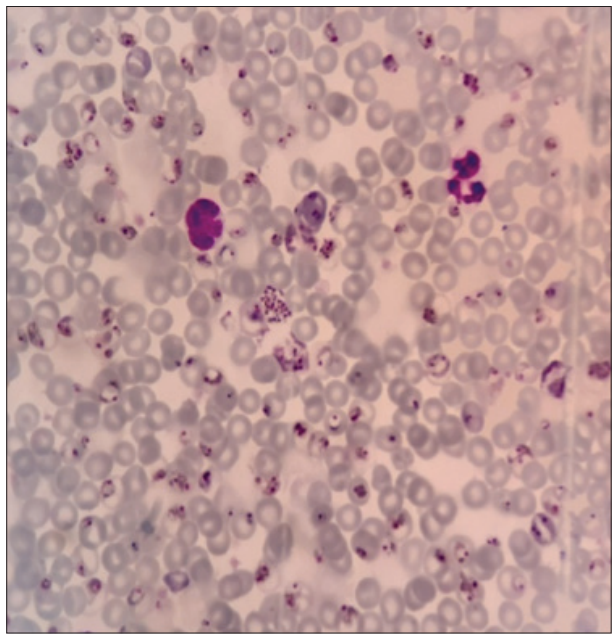

Resim 3. SF (20 mg/kg) 8. gün (\%14 parazitemi).

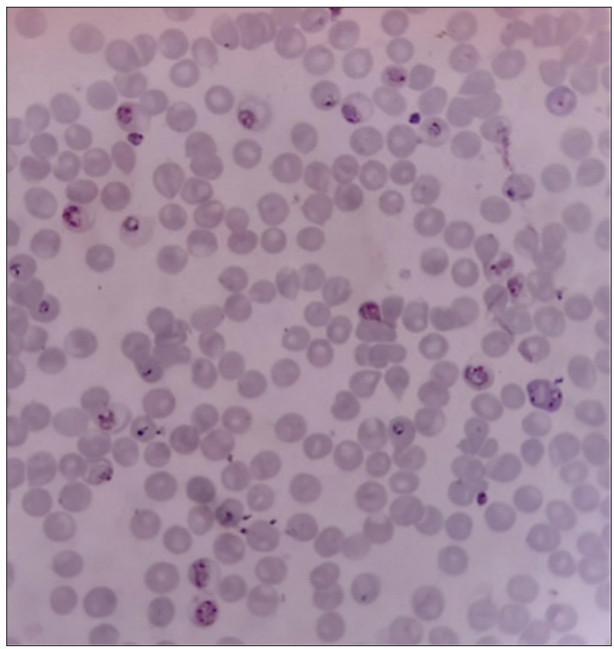

Resim 5. OM (20 mg/kg) 8. gün (\%7.1 parazitemi).

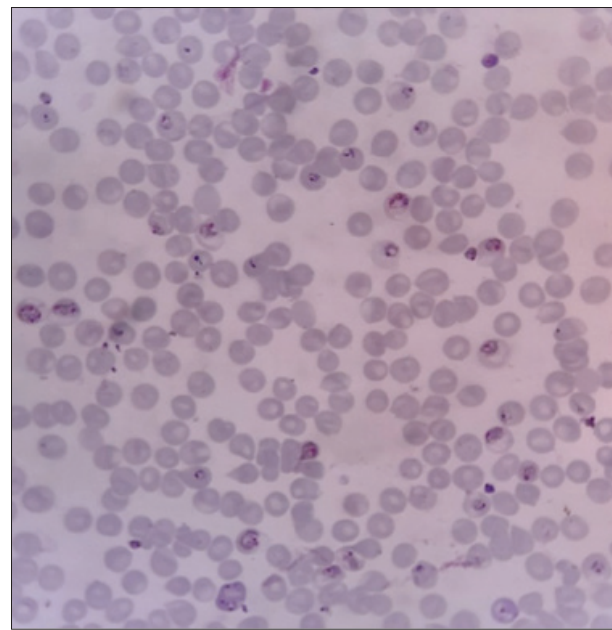

Resim 4. OD (20 mg/kg) 8. gün (\%7 parazitemi).

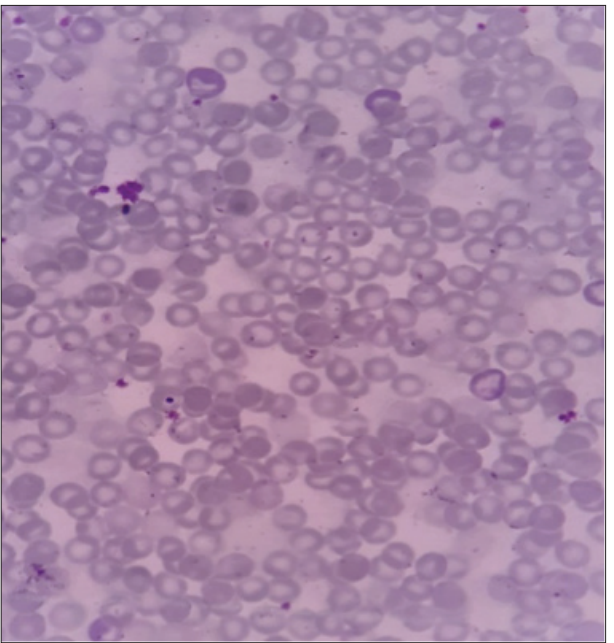

Resim 6. KG (50 mg/kg) 8. gün (\%0 parazitemi).

Çin'de birkaç yüzyıldır geleneksel tıp, klinik alanda yer bulmaktadır². Konvansiyonel ilaçların artan yan etkileri ve sıtma parazitlerinin geliştirdiği ilaç direnci global bir sorun oluşturmakta ve bu sebeple antimalaryal ajanların araştırılması önem kazanmaktadır. Yapı ve biyolojik aktivitelerinden dolayı antimalaryal kemoterapide tıbbi bitkilerin büyük katkısı olduğu bilinmektedir ${ }^{3}$. Bu nedenle, P.berghei ile enfekte fareler üzerinde yeni ve alternatif etken madde taramaları yapıldığı bildirilmektedir².

Çalışmamızda kullanılan OD türü kekik yağının P.berghei paraziti üzerine etkili bir uçucu yağ olduğu görülmüştür. Buna rağmen, tüm çalışma gruplarımız arasında farelerin yaşam sürelerini iki katından fazla (TAKG'de göre 12 gün) artıran bu kekik türünün, fare 


\begin{tabular}{|lcccccccc}
\hline \multicolumn{7}{l}{ Tablo IV. Gruplar Arası Yaşam Sürelerinin One-Way ANOVA Testi Sonucu Istatistiksel Verileri } \\
\hline Grup & $\mathbf{n}$ & $\begin{array}{c}\text { Aritmetik } \\
\text { ortalama }\end{array}$ & $\begin{array}{c}\text { Standart } \\
\text { sapma }\end{array}$ & $\begin{array}{c}\text { Minimum } \\
\text { yaşam süresi }\end{array}$ & $\begin{array}{c}\text { Maksimum } \\
\text { yaşam süresi }\end{array}$ & F & P \\
\hline OM & 6 & 22.50 & 2.074 & 21 & 26 & & \\
OD & 6 & 21.17 & 2.787 & 17 & 24 & & \\
SF & 6 & 13.83 & 1.169 & 13 & 16 & & \\
LN & 6 & 14.17 & 1.329 & 13 & 16 & 54.744 & $<0.001$ \\
TAKG & 6 & 9.50 & 1.049 & 8 & 11 & & \\
Toplam & 30 & 16.23 & 5.237 & 8 & 26 & & \\
\hline
\end{tabular}

OD: Origanum dubium, OM: Origanum majorana, SF: Salvia fruticosa, LN: Laurus nobilis, TAKG: Tedavi almamış kontrol grubu.

Tablo V. Gruplar Arası İstatistiksel Karşılaştırmada Tukey HSD Sonuçları

\begin{tabular}{lccc}
\hline Gruplar & $\mathbf{p}$ & Gruplar & $\mathbf{p}$ \\
\hline OM-OD & 0.706 & OD-SF & $<0.0001^{*}$ \\
OM-SF & $<0.0001^{*}$ & OD-LN & $<0.0001^{*}$ \\
OM-LN & $<0.0001^{*}$ & SF-LN & 0.998 \\
\hline * Aralarındaki fark istatistiksel olarak anlamlıdır. & & \\
\hline
\end{tabular}

fibroblast hücreleri için toksik özellikte olduğu saptanmıştır. Bu kekik yağında majör komponent olarak karvakrol (\%81.8) bulunduğundan dolayı antimalaryal etkisinin olduğu düşünülmektedir. Yapılan çalışmalarda kekik türlerinin yüksek oranlarda karvakrol içerdiği bilinmektedir. On farklı OD klonunu inceleyen Turgut ve arkadaşlarının çalışmasında ${ }^{13}$ \%81.85 ile \%91.04 oranları arasında karvakrol düzeyi tanımlanmışıı. Güney Kıbrıs bölgesinde yılın iki farklı döneminde toplanan OD bitkisinden, çalışmamıza benzer şekilde \%71.3 ve \%69.5 oranlarında majör bileşik olarak karvakrol elde edilmiştir. Norazsida ve arkadaşlarının çalışmasında, karvakrolce zengin (\%85.1) Plectranthus amboinicus bitkisinden elde edilen uçucu yağın P.berghei tedavisinde profilaktik ajan olarak kullanılabileceği saptanmıştır. Yine aynı araştırmada P.amboinicus bitkisinin kemirgen sıtma enfeksiyonunu tedavi edebilecek potansiyel bir doğal ürün olduğu ileri sürülmüştür ${ }^{14,15}$. El Babili ve arkadaşlarının çalışmasında ${ }^{16}$ ise farklı bir kekik türünün (Origanum compactum) anti-P. falciparum etkisi in vitro ortamda araştıııımışıı. íki farklı klorokin dirençli P.falciparum'un kullanıldığı çalışmada, kekikten elde edilen uçucu yağın ve etil asetat ekstraktının antimalaryal aktivitesi olduğu tespit edilmiştir. Bunun yanında, antimalaryal etkisi denenen kekik türünde, majör komponent olarak sırasıyla karvakrol (\%36.5), timol (\%29.7) ve $p$-simen (\%24.3) bulunmuştur.

Terpinen-4-ol ve cis-Sabinen hidrat, çalışmamızda kullanılan OM bitkisinden majör bileşik olarak izole edilen monoterpenlerdendir. Ramos ve arkadaşları ${ }^{17}$, antibakteriyel etkinliğini inceledikleri çalışmalarında, bu kekik türünde ana komponent olarak \%30.2 oranında cis-Sabinen hidrat ve \%28.8 oranında terpinen-4-ol bulmuşlardır. Çalışmamız- 
da, Ramos ve arkadaşlarının araştırmasına göre biraz daha düşük majör bileşik oranları elde edilmiştir. Buna rağmen, Türkiye'de yetişen OM türünde ise tamamen farklı bir durum söz konusudur. Bağcı ve arkadaşlarının yaptığı bir çalışmada ${ }^{18}$, ana madde olarak karvakrol bulunmuş fakat taze ve kuru kekikteki bileşik oranlarının farklılık gösterdiğini tespit edilmiştir. İki farklı OM kekiği kullanılan çalışmada, kurutulmuş bitkilerden \%80.33 ve $\% 83.46$, tazelerinden ise $\% 56.39$ ve $\% 69.49$ oranlarında karvakrol saptanmıştır. Küba, Brezilya, Macaristan ve Tunus'ta ise majör komponentlerin terpinen-4-ol, $\gamma$-terpinen ve linalol olduğu rapor edilmiştir ${ }^{17}$.

OM ve Origanum vulgare türlerinin antimalaryal aktivitesini inceleyen Hussain ve arkadaşlarının çalışmasında ${ }^{19}$, yalnızca O.vulgare yağının antimalaryal etkisinin olduğu tespit edilmiştir. Bu araştırmada, OM majör bileşenlerinin \%20.9 terpinen-4-ol, \%15.7 linalol ve \%13.4 limonen; O.vulgare majör bileşenlerinin ise \%21.6 timol, \%18.8 karvakrol ve \%13.5 o-simen olduğu bulunmuştur. Çalışmamızda, OM kekiğinden elde edilen uçucu yağın, P.berghei'ye karşı en etkili (yaşam sürelerini TAKG'ye göre 14 gün artırdı) madde olduğu görülmüştür. OD ile karşılaştırıldığında OM yağının fare fibroblast hücrelerine sitotoksik etkisinin olmadığı ve güvenilir bir doğal ürün olduğu tespit edilmiştir.

LN (defne)'nin esas yayılış alanı Akdeniz Havzası ve Anadolu'dur. Bu bölgeler dışında Avrupa ve Amerika kıtalarında defne bitkisi yetiştiriciliği yapılmaktadır. Başta Türkiye olmak üzere tüm Batı Akdeniz Havzasında yetişen defne uçucu yağında majör bileşik olarak 1.8-sineol (ökaliptol/ökaliptüs yağı) bulunmaktadır. Karık ve arkadaşlarının çalışmasında, Türkiye'nin Akdeniz, Ege, Marmara ve Karadeniz Bölgelerinden toplanan 100 farklı defne bitkisinden elde edilen uçucu yağlarda \%31.87-67.56 oranında 1.8-sineol tespit edilmiştir ${ }^{20,21}$. Türkiye'nin Aydın ilinden toplanan LN yaprağında ana bileşik olarak \%28.46 oranında kamfen bulunmuş, fakat İzmir'in Çiğli ilçesinde toplanan yapraklarda ise ana komponentin \%34.08 oranında 1.8-sineol olduğu rapor edilmiştir ${ }^{22}$. İran'da yapılan diğer bir araştırmada, defnenin vejetatif, tomurcuk, çiçek ve tohum dönemlerinde ana bileşik olarak \%31.4-35.7 oranlarında 1.8-sineol elde edilmiştir ${ }^{23}$. Çalışmamızda da, LN uçucu yağındaki majör komponent olan 1.8-sineol, literatürle benzer oranlarda bulunmuştur (\%57.2).

Literatürde LN bitkisiyle ilgili antimalaryal etkinlik denemelerine rastlanmamıştır. Fakat LN'nin antiparazitik aktivitesini inceleyen bir araştırmada, bitki yapraklarıyla hazırlanan ekstraktların özellikle Cryptococcus neoformans ve Leishmania donovani promastigot ve amastigotlarına karşı yüksek derecede etkili olduğu bulunmuş, bunun yanında kan parazitlerinden biri olan Trypanosoma brucei'ye karşı da etkisinin olduğu görülmüştür ${ }^{24}$.

Salvia türleri özellikle Kuzey Yarım Küre'nin Akdeniz Bölgesi'nde yayılım göstermektedir. Türkçede adaçayı olarak bilinen, genelde hoş kokulu bitkilerin yer aldığı Salvia türleri uçucu ve aromatik yağ içermelerinden dolayı farmakoloji ve parfümeri sanayinde önemli sayılmaktadır ${ }^{25}$. Yapılan çalışmalarda, SF uçucu yağında predominant bileşenin 1.8-sineol (\%52.8) olduğu tespit edilmiştir. Bunun yanında kamfor (\%5.8), $\alpha$-pinen (\%5.8), $\beta$-pinen (\%4.5), mirsen (\%3.8) ve kamfen (\%3.1) bileşenleri olmak üzere $\% 1$ 'in üzerinde 
toplam 15 komponent belirlenmiştir. İçerisindeki 1.8-sineol, kamfor, $\alpha$-pinen, $\beta$-pinen ve kamfen bileşenlerinin tıbbi açıdan önemli olduğu kanıtlanmıştır ${ }^{26,27}$. Türkiye'de adaçayı türlerindeki bileşenlerin örneklere göre değişim gösterdiği anlaşılmış ve 1.8-sineol oranının \%23.2-37.3 arasında değiştiği görülmüştür ${ }^{28}$.

Yapılan araştırmalarda 1.8-sineol içeren bitki yağlarının antiparazitik etkisi olduğu tespit edilmiş, hatta in vitro ortamda iki farklı (klorokin-dirençli ve klorokin-duyarlı) P.falciparum suşunun üremesini inhibe ettiği görülmüştür. Ayrıca bu inhibisyonun, parazitin erken trofozoit dönemini etkilediği tespit edilmiştir ${ }^{29}$. Kamatou ve arkadaşlarının çalışmasında ${ }^{30}$ ise, Salvia türlerinin antimalaryal aktiviteye sahip olduğu vurgulanmış ve özellikle Salvia radula türünün P.falciparum'a karşı en etkili tür olduğu saptanmıştır.

Çalışmamızda, LN ve SF uçucu yağının P.berghei ile enfekte farelerin yaşam sürelerinde, OM ve OD'ye göre daha az oranda anlamlı bir artışa (TAKG'ye göre 5 gün) neden olduğu görülmüştür. Sayısız biyolojik aktiviteye sahip olan bu bitkilerin, fare fibroblast hücrelerine sitotoksik etkisinin bulunmadığı ve in vivo çalışmamızda az da olsa antimalaryal etkilerinin olduğu tespit edilmiştir.

Çalışmamız, Kuzey Kıbrıs'ta bitki yağlarında antimalaryal etkinlik araştırılması alanında yapılmış ilk araştırma olma özelliğindedir. Antimalaryal etki gösteren, parazitemiyi düşürerek farelerin yaşam süresini iki katından fazla artıran, Kıbrıs endemik bitkilerinden OM (TAKG'ye göre 14 gün artış) ve yine aynı cinsten OD (TAKG'ye göre 12 gün artış)'nin, antimalaryal moleküllerin elde edilmesine kaynaklık edebileceği görülmüştür. Bunun yanında LN ve SF uçucu yağlarının da P.berghei'ye karşı etkili olduğu tespit edilmiştir. Aktivite gözlenen bitkilerin profilaktik amaçlı kullanılması olasılığı da yüksektir. İleri çalışmalar ile antimalaryal etkisi saptanacak Kuzey Kıbrıs bitkilerinin kültüre alınması, aktiviteden sorumlu maddelerin hücre süspansiyonunun yapılması, doku kültürü teknikleri ile laboratuvar şartlarında daha yüksek miktarlarda üretilmesi ve aktivite mekanizmalarının belirlendiği takdirde enzimlerle selektif olarak etkileşime girebilecek olan moleküllerin tasarlanması yapılabilecektir. Elde edilecek bu aktif bileşenler ilaç sanayinde de kullanılarak yeni ilaç molekül modellerinin keşfinde rol oynayabilecektir. Ayrıca hem ülke ekonomisine hem de dünya sağlığına katkı sağlayabileceği kanısındayız.

\section{TEŞEKKÜR}

Çalışmamızda kullanılan P.berghei suşunun temininde Manisa Celal Bayar Üniversitesi Tıp Fakültesi, Parazitoloji Bankasına, uçucu yağların elde edilmesinde YDü Sağlık Bilimleri Enstitü Müdürü, Prof. Dr. K. Hüsnü Can Başer'e, istatistiksel analizlerde Tıp Fakültesi Biyoistatistik Anabilim Dalı Başkanı Prof. Dr. İlker Etikan'a ve deney hayvanları çalışmalarındaki yardımlarından dolayı YDÜ Deney Hayvanları Laboratuvarı sorumlusu Veteriner Hekim M. Melis Temizel'e teşekkür ederiz.

\section{ETIK KURUL ONAYI}

Bu çalışma, Yakın Doğu Üniversitesi Hayvan Deneyleri Yerel Etik Kurulu onayı ile gerçekleştirildi (Tarih: 27.03.2019 ve Karar no: 2019-03). 


\section{ÇIKAR ÇATIŞMASI}

Yazarlar bu makale ile ilgili herhangi bir çıkar çatışması bildirmemişlerdir.

\section{KAYNAKLAR}

1. Başaran S, Şimşek Yavuz S, Çağatay A, Öncül O, Özsüt H, Eraksoy H. Imported malaria caused by Plasmodium falciparum: A global problem. Klimik Dergisi 2017; 30(3): 120-5.

2. Toma A, Deyno S, Fikru A, Eyado A, Beale A. In vivo antiplasmodial and toxicological effect of crude ethanol extract of Echinops kebericho traditionally used in treatment of malaria in Ethiopia. Malar J 2015; 14: 196.

3. Mzena T, Swai H, Chacha M. Antimalarial activity of Cucumis metuliferus and Lippia kituiensis against Plasmodium berghei infection in mice. Res Rep Trop Med 2018; 9: 81-8.

4. World Health Organization. World malaria report 2018. Available from: https://www.who.int/malaria/ publications/world-malaria-report-2018/en/

5. World Health Organization. Malaria. 24 April 2020. Available from: https://www.who.int/news-room/factsheets/detail/malaria

6. An A. Tıp Alanındaki Illk Kıbrıslı Türkler. Kıbrıs Türk Tabibleri Birliği Yayını, Işık Kitapevi, 2014.

7. Kuzey Kıbrıs Türk Cumhuriyeti Sağlık Bakanlığı, Bildirimi Zorunlu Hastalıklar. Available from: http://saglik. gov.ct.tr/iSTATISTIKI-BILGILER/Bildirimim-Zorunlu-Hastalıklar

8. Dame ZT, Petros B, Mekonnen Y. Evaluation of anti-Plasmodium berghei activity crude and column fractions of extracts from Withania somnifera. Turk J Biol 2013; 37: 147-50.

9. Mulisa E, Girma B, Tesema S, Yohannes M, Zemene E, Amelo W. Evaluation of in vivo antimalarial activities of leaves of Moringa oleifera against Plasmodium berghei in mice. Jundishapur J Nat Pharm Prod 2018; 13(1): e60426.

10. Salman Ö, Erbaydar T. İlaç dirençli sıtma. TAF Prev Med Bull 2016; 15(4): 368-75.

11. Özbilgin A, Çavuş I, Nuraydın A, Kaya T. In vivo and in vitro models for scanning grug substances in malaria: Prestudy. Turkiye Parazitol Derg 2017; 41: 156-63.

12. Özbilgin A, Östan I, Kurt Ö, Balcıoğlu iC. Kan İncelemeleri, pp: 63-79. In: Korkmaz M, Ok ZÜ (editörler), Parazitolojide Laboratuvar Yöntem Yorum Akreditasyon. 2011, Yayın No: 23. Türkiye Parazitoloji Derneği, İzmir.

13. Turgut K, Özyiğit Y, Tütüncü B, Uçar Sözmen E. Agronomic and chemical performance of selected Origanum dubium Boiss. clones for industrial use. Turk J Agric For 2017; 41: 272-7.

14. Karioti A, Vrahimi-Hadjilouca T, Droushiotis D, Rancic A, Hadjipavlou-Litina D, Skaltsa H. Analysis of the essential oil of Origanum dubium growing wild in Cyprus. Investigation of its antioxidant capacity and antimicrobial activity. Planta Med 2006; 72(14): 1330-4.

15. Norazsida R, Pakeer O, Taher M. The antimalarial properties of essential oils of the leaves of malaysian Plectranthus amboinicus (Lour) spreng in mice infected with Plasmodium berghei. IMJM 2017; 16(1): 67-74.

16. El Babili F, Bouajila J, Souchard JP, Bertrand C, Bellvert F, Fouraste I, et al. Oregano: Chemical analysis and evaluation of its antimalarial, antioxidant, and cytotoxic activities. J Food Sci 2011; 76(3): 512-8.

17. Ramos S, Rojas LB, Lucena ME, Meccia G, Usubillaga A. Chemical composition and antibacterial activity of Origanum majorana L. essential oil from the Venezuelan Andes. Journal of Essential Oil Research 2011; 23(5): 45-9.

18. Bağci Y, Kan Y, Doğu S, Çelik SA. The essential oil compositions of Origanum majorana L. cultivated in Konya and collected from Mersin-Turkey. Indian Journal of Pharmaceutical Education and Research 2017; 51(3): 463-9.

19. Hussain Al, Anwar F, Rasheed S, Nigam PS, Janneh O, Sarker SD. Composition, antioxidant and chemotherapeutic properties of the essential oils from two Origanum species growing in Pakistan. Brazilian Journal of Pharmacognosy 2011; 21(6): 943-52. 
20. Karık Ü, Çiçek F, Oğur E, Tutar M, Ayas F. Türkiye defne (Laurus nobilis L.) populasyonlarının uçucu yağ bileşenleri. ANADOLU Ege Tarımsal Araştırma Enstitüsü Dergisi 2015; 25(1): 1-16.

21. Caputo L, Nazzaro F, Souza LF, Aliberti L, De Martino L, Fratianni F, et al. Laurus nobilis: composition of essential oil and its biological activities. Molecules 2017; 22: 930.

22. Sevindik E, Aydin S, Apaydin E, Okan K, Efe F. Antibacterial and antifungal activities of essential oils from Laurus nobilis L. flowers and leaves grown in the West Anatolian area. Fresenius Environmental Bulletin 2019; 28(9): 6555-9.

23. Verdian-rizi M, Hadjiakhoondi A. Essential oil composition of Laurus nobilis L. of different growth stages growing in Iran. Z Naturforsch C J Biosci 2008; 63(11-12): 785-8.

24. Dharmaratne HRW, Jain S, Tekwani BL, Jacob MR, Dhammika Nanayakkara NP. Antifungal and antiparasitic activities of Laurus nobilis (bay leaves). Planta Med 2015; 81-PK17.

25. Akıcı N. Bazı Salvia Türlerinin Biyokimyasal Özelliklerinin Belirlenmesi. T.C. Balıkesir Üniversitesi, Yüksek Lisans Tezi, 2018, Balıkesir.

26. Aşkun T, Başer KHC, Tümen G, Kürkçüoğlu M. Characterization of essential oils of some Salvia species and their antimycobacterial activities. Turk J Biol 2010; 34(1): 89-95.

27. Fu Z, Wang H, Hu X, Sun Z, Han C. The pharmacological properties of Salvia essential oils. J Appl Pharma Sci 2013; 3(7): 122-7.

28. Karık Ü, Sağlam AC. Tekirdağ ekolojik koşullarında Anadolu Adaçayı (Salvia fruticosa Mill.) popülasyonlarının verim ve kalite özelliklerinin belirlenmesi. Tarla Bitkileri Merkez Araştırma Enstitüsü Dergisi 2017; 26(2): 203-15.

29. Su V, King D, Woodrow I, McFadden G, Gleadow R. Plasmodium falciparum growth is arrested by monoterpenes from eucalyptus oil. Flavour Fragr J 2008; 23(5): 315-8.

30. Kamatou GPP, Van Zyl RL, Davids H, Van Heerden FR, Lourens ACU, Viljoen AM. Antimalarial and anticancer activities of selected South African Salvia species and isolated compounds from S.radula. South African Journal of Botany 2008; 74(2): 238-43. 